\title{
Awareness of Integrated Reporting in Ghana :A Case Study at Asante Akim Central Municipality
}

\author{
Job Boahen ${ }^{1}$, Dr. Ephraim Awinbugri Armstrong ${ }^{2}$ \\ ${ }^{l} P h D_{(c)}$ Accounting, Valley View University, Ghana \\ ${ }^{2}$ Lecturer (CODeL), University of Education, Winneba, Ghana
}

\begin{abstract}
The advocacy of the International Integrated Reporting Council (IIRC) focuses on the adoption of integrated reporting (I.R.) to mitigate the apparent lapses of corporate social responsibility (C.S.R.) reports. In Ghana, MMDAs serve as development agents, and comprehensive financial and integrated reporting is critical for stakeholders' trust and investors' willingness to engage in the Assembly.
\end{abstract}

The research used a quantitative research design, with 100 respondents out of a total population of 250 receiving questionnaires. Using the Statistical Product and Service Solutions, the researcher used descriptive statistics to analyse the data (SPSS, 22.0).

The findings show that even though there is $85 \%$ awareness of integrated reporting and its apparent benefits, the Assembly is yet to fully adopt I.R. in its reporting process. The study thus recommended full adoption of I.R. by the Assembly as a means of adherence to the assurance standards ISAE3000 and AA1000AS and enhanced public confidence in its reporting process, leading to attraction of investors therein.

The research concluded that there was a high level of awareness of integrated reporting at Asante Akim Central Municipality.

Key Words: Integrated reporting, Asante Akim Central Municipality, Ghana

\section{INTRODUCTION}

$\mathrm{M}$ ost companies have been progressively disclosing information about their non-financial performance and engaging in integrated reporting (I.R.) in addition to standard financial reporting in recent years because investors and various stakeholders have demanded holistic reporting by them (Selimoglu \& Yesilcelebi, 2021). Integrated reporting combines environmental accounting, social accounting, governance (E.S.G.) report and the standard financial report into one composite report for stakeholders to enhance their understanding of companies' operations. Investors are the primary recipients of these reports, and there is preliminary evidence that they appreciate non-financial data (Aras, Kutlu Furtuna, \& Hacioglu Kazak, 2021).

The integrated report pulls together material information about an organisation's strategy, governance, performance, and prospects in a way that reflects the company's commercial, social, and environmental context (Aras et al.,2021). It combines financial data with social and environmental data to offer stakeholders a comprehensive picture of the organisation's management and performance (Selimoglu et al., 2021).

In many aspects, Integrated Reporting differs from financial statements and corporate social responsibility reports. Instead of discrete C.S.R. reporting, Integrated Reporting includes a company's financial, economic, governance, and social dimensions. The I.R. focuses on various stakeholders and gives more excellent reporting on the company's future outlook and strategic conversation that connects the past to the future (Bananuka, Juma, Zainabu Tumwebaze, \& Orobia,2019).

\subsection{Background of Integrated Reporting}

South Africa's first King Code of Corporate Governance Principles, sometimes known as 'King I,' was released in 1994, kicking off the Integrated Reporting journey. King I was named after Mervyn King, a former Supreme Court of South Africa justice who "was particularly known for its inclusive stakeholder (rather than primary shareholder) view of the corporation's purview" (King Report IV,2016). The King I report was written in South Africa as the country "began on the path to real democracy, the private sector understood that it, too, required a new form of governance" (King Report IV,2016), and like other more industrialised and democratic countries, such as the United Kingdom, were developing corporate governance frameworks (King Report IV,2016). Mervyn King, motivated by the Johannesburg Earth Summit, realised that "King I" needed to be rewritten and released the King II report in 2002 (King Report IV,2016). Following that, the King II report proposed the notion of "Integrated Sustainability Reporting". It established a task force to "analyse many new and challenging aspects of nonfinancial reporting" (Ernest \& Young,2019). This new report was built on the foundations of the Global Reporting Initiative (G.R.I.) and triple bottom line reporting. Following the fall of Enron and WorldCom, parts of King II were adopted by the New York Stock Exchange and included in the SarbanesOxley Act. As a result, King's concept of corporate governance had a significant impact on worldwide corporate governance norms. In South Africa, the current version is based on the King Report on Governance for South Africa 2009 (King Report IV,2016), which calls for a holistic and integrated portrayal of a company's financial and sustainability performance. It advocates that the market capitalisation of any company listed on the Johannesburg 
Stock Exchange should be equal to its economic value and not its book value. As seen in its balance sheet and profit and loss statement, a company's financial report is a snapshot of its financial situation at a specific point in time. When a person buys a stock on a stock exchange, they assess the company's economic value. Future earnings, brand, goodwill, the quality of its board and management, reputation, strategy, and other sustainability characteristics are all considered in the evaluation. The informed investor evaluates the company's risk management and considering the company's long-term sustainability challenges.

Accordingly, King III contains a set of principles for integrated reporting, and on March 1 2010, the Johannesburg Stock Exchange (J.S.E.) mandated a voluntary "apply or explain basis" (Gerwanski, Kordsachia, \& Velte, 2019). King III advocates the voluntary basis because "there are always ways of getting around a rule. It is much more difficult to get past a principle" (Gerwanski et al.,2019). South Africa is now the only country that requires applicants to "apply or explain." However, in 2009, Sir Michael Peat of the Prince of Wales's Accounting for Sustainability Project (A4S), Paul Druckman of the G.R.I., and Mervyn King met over a 'cup of tea' to examine how the A4S and the G.R.I. could merge. The famous St James's Palace (London) meeting on September 11, 2009, was significant because, as Elkington (2009) explains, it was the first time that two of the most important bodies in the reporting field, Accounting for Sustainability (founded by H.R.H. The Prince of Wales) and the Global Reporting Initiative (where I sit on the Board), had co-hosted leading organisations. In addition, "a draft of a new book by Harvard Business School's Bob Eccles and Grant Thornton's Mike Krzus" was discussed at the meeting (Carol,2018). As a result, in 2010, the International Integrated Reported Committee was formed. In 2011, the first Discussion Paper was released with the purpose of "filling the needs of the twenty-first century" by "expanding on the foundations of financial, management commentary, governance and remuneration, and sustainability reporting in a way that recognizes their interrelationship" (Aras et al.,2019). Since 2009, the IIRC (now known as the International Integrated Reporting Council) has released a proposed framework, which has received a comment from interested stakeholders (respondents) and resulted in the publication of the International framework in December 2013. (IIRC, 2013).

\subsection{Research Objectives}

The ultimate goal of the study is to examine the level of awareness of integrated reporting in Ghana's district assemblies, specifically Asante Akim Central Municipality.

The specific objectives were to:

1) Determine the extent of awareness of integrated reporting at Asante Akim Central Municipal Assembly
2) Assess the effectiveness and applicability of integrated reporting at the Asante Akim Central Municipal Assembly.

\subsection{Research Questions}

The following research questions are put forth to unravel the above objects of the study:

1) What is the level of awareness of integrated reporting at Asante Akim Central Municipal Assembly?

2) To what extent is integrated reporting applicable in the financial reporting framework at Asante Akim Municipal Assembly?

\subsection{Problem Statement}

Several companies have used the traditional financial reporting system as a catalyst for creative accounting leading to the collapse of most companies (Awinbugri \& Boahen, 2021). This necessitates the adoption of integrated reporting to curb the menace. Unfortunately, the concept of integrated reporting in Ghana is least researched, especially from the perspective of municipal assemblies except (Haruna \& Msizi, 2020), whose focus was on the stock exchange.

Additionally, G.R.I. (2013a) posits that $46 \%$ of reports listed on G.R.I.'s sustainability disclosure database in 2012 indicated some external assurance. In 2015, 92\% of the world's 250 largest companies (G250) presented a corporate C.S.R. report, and almost two-thirds (63\%) had been independently assured (KPMG, 2015). Whilst much has been done to ameliorate the quality of the sustainability information presented, a paucity of informed assurance related to C.S.R. reporting remains in Ghana (Ernest\& Young, 2018).

\section{LITERATURE REVIEW}

\subsection{Integrated reporting in Ghana}

According to a study done by Haruna M. and Msizi M., listed companies on the Ghana Stock Exchange made more positive environmental and social disclosures than balanced disclosures, implying that the companies used Integrated Reporting to manage their respective images. The companies attempted to fulfil their strategic goals by releasing data that portrayed them in a positive light.(Haruna \& Msizi , 2020).

Rinaldi, Unerman, and de Villiers, (2018) making a comparative analysis of integrated reporting in ten countries, concluded that the best way to speed its adoption is for the corporate and investment communities to mobilise to drive adoption and improve the quality of integrated reporting for the benefit of both shareholders and society at large.

Although many stakeholders benefit from the adoption of integrated reporting across the world, little seems to be known to stakeholders in Ghana. Due to this, stakeholders in Ghana have failed to press home, and for that matter, corporate industries choose and pick whatever reporting style suits them. It is also apparent that research into integrated reporting in Ghana is minimal. All these problems could result from the 
fact various stakeholders in the country are not aware of the integrated reporting and its associated benefits to stakeholders. The study, therefore, seeks to test the level of awareness of integrated reporting by stakeholders in Ghana.

\subsection{Theoretical Review}

According to the literature, seven theories can be used to explain why companies disclose non-financial information. These theories are legitimacy theory, stakeholder theory, signalling theory, agency theory, positive accounting theory, institutional theory, and intergenerational equity theory. The following section dives into the various hypotheses that have been proposed to explain integrated reporting.

\subsubsection{Legitimacy Theory}

Several academics have used legitimacy theory to examine the practices of non-financial information disclosure across corporations( Camillerri, 2018; Maama \& Mkhize,2020). The legitimacy theory is based on the realisation that businesses' support from society is critical to their growth, image, and long-term viability. These businesses and organisations voluntarily share non-financial information as a persuasive tool to enable the community to regard their presence and actions as legitimate, authentic, supporting, and suitable to earn and sustain such support (Maama \& Mkhize, 2020). It implies that the legitimacy theory is inextricably linked to the concept of a social contract, which emphasises an organisation's reliance on its surroundings, societal expectations and attempts to rationalise its presence in society through legitimising its activities (Camillerri,2018). The term "legitimacy" refers to a company's desire to be perceived as responsible. As a result, Maama and Mkhize (2020) identified four legitimacy techniques businesses use: educating society about the organisation's purpose, changing society's view of the company's operations, distracting or manipulating society's attention, and changing society's expectations. It means that when society requires it, businesses are more likely to share information about their operations, particularly those addressing social and environmental factors. As a result, proponents of non-financial information releases argue that transparency, communication, and responsibility are the most important motivations for businesses to engage in C.S.R. and environmentally friendly initiative. According to several research studies on legitimacy theory, NFI disclosure is primarily used to achieve an organisation's goals. The outcomes of previous investigations tend to point to a legitimate reason for NFI disclosure. Maama and Mkhize (2020) examined the differences in non-financial information disclosure policies adopted by Australian firms during the era of established environmental prosecutions and found that prosecuted firms made more positive environmental disclosures in the year they were prosecuted than in any other year. The authors discovered that not penalised corporations published more positive social and environmental information, possibly diverting attention away from their environmental violations. Omran and Ramdhony, (2015) presented a similar observation, claiming that the willingness to disclose environmental and social information is similarly linked to society's overall attention to reporting firms. According to the authors, a low degree of NFI disclosure could be attributed to a company's poor assessment of society's opinion. The contradictory data reported above may indicate that a legitimacy theoretical perspective is insufficient to explain NFI disclosure. According to the research, the legitimacy hypothesis is linked to the incentive to participate in corporate social responsibility and environmentally friendly activities and reporting. In recent years, this has resulted in more non-financial information being disclosed. If the goal was to raise accountability by increased reporting, this could have resulted in augmented accountability. Furthermore, while examining NFI disclosure from the managerial stakeholder's perspective, the concept of achieving legitimacy with specific stakeholders is worthwhile.

\subsubsection{Stakeholder Theory}

The stakeholder theory recognises that different stakeholder groups have different perspectives on how a company should be run (Camillerri,2018). As the name suggests, the stakeholder theory involves stakeholders (Maama \& Mkhize, 2020), who are persons, groups of people, institutions, or organisations connected with a corporation in a legitimate capacity. This means that there are numerous opinions from significant players involved in investing, advocating, and procuring. Camillerri,(2018) assert a natural link between the concept of environmental or social responsibility and the interests of a firm's stakeholders. The idea of a stakeholder personalises social and environmental duties by identifying the specific groups or individuals that companies must address in their corporate non-financial information disclosure approach. Maama and Mkhize (2020) found a scarcity of studies examining stakeholders' opinions on non-financial information disclosures in a review study on the topic. Because stakeholders rely on trustworthy and relevant NFI to make decisions, (Omran et al.,2015) argue that enterprises and organisations must supply this information to aid their decision-making process. According to Deegan (2019), corporate environmental and social responsibility, as well as reporting, can be investigated by looking at the decisions taken at the company or organisational level to meet the expectations of key stakeholders. According to the writers, there are no requirements as to whether or not information must be made available to whom or what kind of information should be shared. Corporate information disclosures or reporting, on the other hand, are seen as a way for firms to address the demands of stakeholders who are considered critical to the organisation's future survival and existence. Deegan (2019) proposed that a strategic stance in light of stakeholders' power provides a foundation for companies to respond to non-financial information disclosure demands while acknowledging that more academic research is needed to develop theories for integrated reporting. Furthermore, because a company has many stakeholders, non-financial 
information disclosure cannot be considered valuable unless it is tailored to all those affected by the accounting organisation. This emphasises the importance of stakeholders' requirements and preferences when it comes to NFI disclosure. Maama and Appiah (2019), Deegan (2019) etc agree that enterprises strategically manage NFI disclosure. According to Deegan (2019), stakeholder groups should be managed in terms of the firm's interests. The more critical the stakeholder is to the firm, the more effort is to manage the relationship. Another viewpoint is that stakeholder theory is separated into two categories: ethical and managerial. The ethical category implies that stakeholders are entitled to decent and equitable treatment. On the other hand, the managerial category argues that stakeholders must be controlled for organisations to prosper. Based on the authority they have over the organisation, the management aspect responds to stakeholders' needs (Deegan,2019). It is self-evident that, while fair and ethical, applying a stakeholder approach to non-financial information disclosure is far from straightforward, and it may be a daily struggle for managers and accountants. What is apparent is that the legitimacy and stakeholder theories are neither mutually exclusive or antagonistic. They are, nevertheless, closely linked and could be utilised to complement one another.

\subsubsection{Signalling Theory}

There is a perception of information gap between management and shareholders, according to the signalling theory. As a result, shareholders may think that management is not disclosing all necessary information. This would result in an imbalance of information between investors and management. As a result, investors would be unwilling to invest more in a company if they didn't have the information required to make a judgment. When the source of the information asymmetry is the information quality or the aim of the information, the signalling theory tackles the information asymmetry that exists between two parties (Su, Peng, Tan, \& Cheung, 2016). The extent to which a party shares its unobservable features in exchange for a premium from the other party is the quality of the information in this context. On the other hand, the goal of the information is to reduce or eliminate the moral risks that arise from a company's conduct. The signalling hypothesis has been utilised by management and accounting researchers to explain the reasons for the adoption of I.R. and the possible benefits connected with good governance, environmental and socially responsible behaviours, and the reporting of these practices. There is evidence that organisations that implement ecologically and socially responsible practices can lessen the issues of information asymmetry between stakeholders themselves and their stakeholders and hence increase financial performance (Su et al.,, 2016). The signalling theory's original concept was based on information asymmetry in the labour market and financial information. However, prior research suggests that including NFI in a firm's reporting practice is a voluntary decision taken by businesses that go beyond the technological, economic, and regulatory needs of the entity (Su et al., 2016). As a result, companies use non-financial data to highlight characteristics that stakeholders such as consumers, suppliers, and staff may overlook. More importantly, according to Maama et al., (2020), these stakeholders value the NFI disclosure procedures' unobserved characteristics. This viewpoint argues that integrated reporting has a similar signalling impact in various institutional settings . Because of the incredible variety of business investments worldwide, the usefulness of integrated reporting as a strategy for managing information asymmetry may be impacted when it is transmitted to various institutional environments . The implication is that the signal's strength may differ depending on the institutional setting. Integrated reporting, as seen in the preceding discussion, can be used as a signal to offer additional non-financial information to critical stakeholders, especially in emerging markets. However, to achieve a quality signal, the integrated reporting technique must meet two characteristics (Su et al.,2016). To begin with, lowperforming companies require more resources and effort to embrace integrated reporting than high-performing companies. The second criterion is that the benefits of implementing integrated reporting outweigh the costs for high-performing enterprises. This is because the adoption and practice of I.R. incur both explicit monetary expenses and implicit managerial costs and lawsuit risk. As can be seen, the signalling theory is conceived in terms of management to influence stakeholders' behaviour and activities, which makes it similar to both the legitimacy and stakeholder theories.

\subsubsection{Agency Theory}

According to the agency theory, the separation of owners and managers of businesses has created difficulty, mainly when their goals are irreconcilable. This conflict of interest arises when management sometimes chooses to maximise their financial interests, even if it means putting the owners' interests at risk (Omran et al., 2015). The problem is known as the principal-agent or agency problem. Investors and other stakeholders are usually focused on the agency problem, and management strives to handle this scenario while making strategic decisions for a company (Omran et al., 2015). Management will occasionally use non-financial facts to show themselves as accountable to avoid the perceived agency problem. This gradually boosts investor confidence, draws more cash, and raises the price of the company's stock (Deegan, 2019). Some research supports the idea that the agency theory promotes management to deliver greater NFI to stakeholders, even if it is against their interests (Deegan, 2019). According to Omran et al., (2015), the agency problem results in significant agency expenses, which shareholders must monitor and eliminate. As a result, shareholders expect additional information from management, particularly nonfinancial information, to prevent management from pursuing their interests at the expense of shareholders.

\subsubsection{Positive Accounting Theory}


Positive accounting theory (PAT), often known as political cost theory, has been presented to explain why companies disclose non-financial information (NFI). Watts and Zimmerman came up with the PAT in 1978.

Camilleri (2018) PAT is based on the idea that firms would generally act to maximise their utility, and as a result, management would fight for accounting standards-based egoism. According to Omran et al., (2015), management must identify elements that are likely to be fundamental to their lobbying behaviour, one of which is to offer E.S.G. information to be viewed as responsible. According to positive accounting theory, a firm is defined as a collection or nexus of contracts (Camilleri, 2018). These agreements are crucial for enlisting the help of self-seeking persons (Camilleri,2018). A firm, for example, has contracts with managers, shareholders/investors, suppliers, customers, employees, and the community. As a result, contracts allow individual parties to act in ways that maximise shareholder profit. Contracting costs, such as negotiation, performance monitoring, and evaluation fees, will be incurred due to this. As a result, positive accounting theory assumes that businesses would always try to reduce contracting costs, which will impact the accounting standards that are implemented. The basic premise here is that a company is a collection of contracts, and accounting systems are an essential component. As a result, businesses publish information such as ethical, governance, social, and environmental data to influence the behaviour of specific groups of people.

\section{METHODOLOGY}

The study used a descriptive survey design and a quantitative research approach. The study makes use of primary data using questionnaires administered to 100 respondents from a population of 250 . The researcher used a convenient sampling technique.

The questions sought to test their knowledge and understanding of integrated reporting. We used a Likert scale to decipher whether respondents were aware and understood integrated reporting. It is believed that high awareness will increase its advocacy and resultant adoption by the government and respective corporate institutions.

Data validity, a prerequisite for the quantitative study, was ensured using exploratory factor analysis (E.F.A.) and confirmatory factor analysis (C.F.A.).

\section{RESEARCH FINDINGS}

\subsection{Profile of Respondents}

Socio-economic attributes of workers affect their productivity at work (Rezagholi, 2016). These include age, education and gender. This study considered the Gender/Sex of respondents, Years of work at the Assembly, Designation of respondents etc.

\subsubsection{Gender Distribution of Respondents}

Out of the 100 respondents, $65 \%$ were males, and $35 \%$ were females. The proportion of males to females is shown in Figure 4.1.

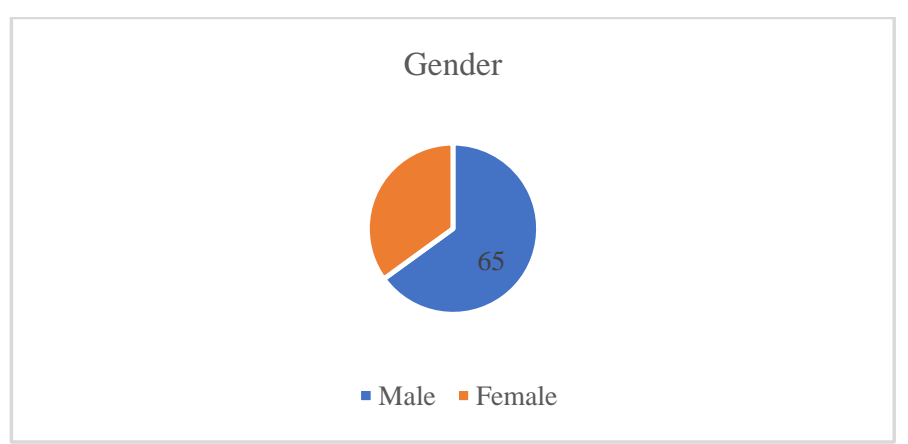

Figure 4.1. Gender distribution of respondents.

Source: Author's Construct, (2021)

\subsubsection{Years of Work}

Figure 4.2 shows that $74 \%$ of the respondents worked at the Assembly between 11 to 20 years, while $20 \%$ worked around 20 years and above and a little over 6\% worked around 1 to 10 years. The Assembly has a lot of old workers, which shows a lot of experience to facilitate the adoption of integrated reporting.

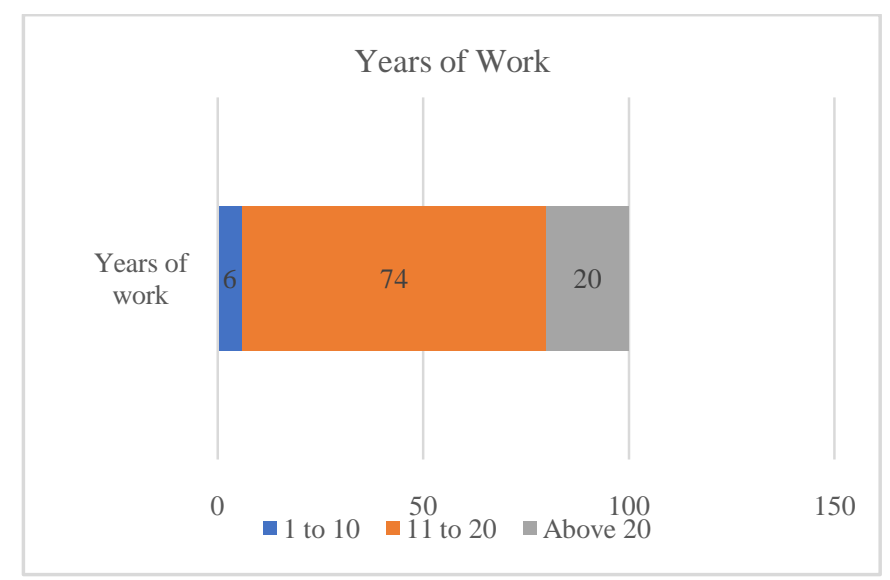

Figure 4.2. Years of work at Asante Akim Central Municipal Assembly.

Source: Author's Construct (2021)

\subsection{Presentation and Discussion of Results}

Presentation and discussion of results would be scrapped to the study objectives elaborated below:

\subsubsection{Awareness of I.R. at Asante Akim Central Municipality}

Figure 4.3 depicts the study's first objective regarding the level of awareness of integrated reporting at Asante Akim Central Municipality. The findings show that $85 \%$ of the respondents were aware or had heard of integrated reporting, while a little over $2 \%$ were neutral and about $13 \%$ unsure of the concept. The Assembly essentially is aware of the concept of I.R. based on the above findings. This finding is in sharp 
contrast with M.I.A. and ACCA (2016) that found low awareness and knowledge of integrated reporting in Malaysia.

Even though the Assembly was aware of the concept of I.R., it was yet to fully adopt it in its reporting process as $65 \%$ of the respondents strongly disagreed that the Assembly currently adopted it.

Additionally, even though the Assembly had yet to adopt I.R., 90\% of the respondents strongly agreed that the Assembly had plans to inculcate I.R. into its reporting process, even though $2 \%$ were unsure and $8 \%$ strongly disagreed with its possibility of adoption. This finding is inconsistent with IIRC(2019) that found high adoption and compliance of I.R. in China, Brazil, India, Japan, Luxemburg, New Zealand, and the United Kingdom.

Last but not least, $98 \%$ of the respondents strongly believed adoption of integrated reporting augmented public confidence leading to increased investor funding.

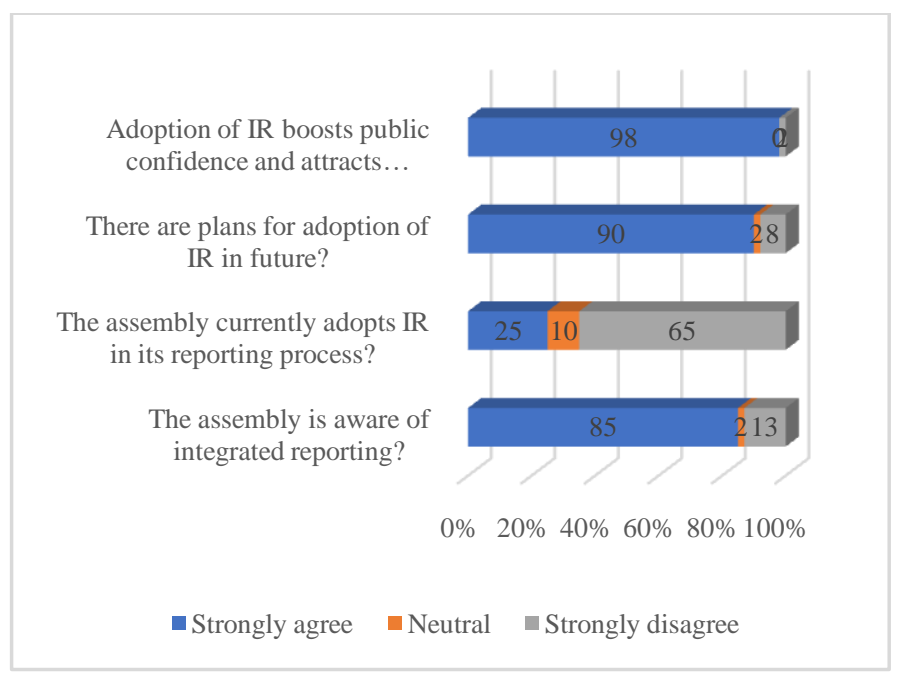

Figure 4.3. Awareness of integrated reporting at Asante Akim Central.

Source: Author's construct,(2021)

\subsubsection{Effectiveness and applicability of I.R. at Asante Akim Central}

The study's second objective was premised on how practical and applicable

Concerning the understanding that integrated reporting was more applicable and practical for listed firms other than municipal assemblies, the respondents were divided as $40 \%$. Each strongly agreed and strongly disagreed with the assertion, whilst $10 \%$ remained neutral. The findings sharply contradict that of KPMG (2017) and IIRC (2019) that reported that large companies worldwide now integrate financial and non-financial disclosures in their annual reports and that more than 1600 institutions, both listed and unquoted in over 70 countries globally, rely on I.R. to support strategy formulation and implementation.
Secondly, about $73 \%$ of the respondents strongly agreed that I.R. was not applicable and practical at the Assembly due to inadequate expertise and resources. In comparison, a handful of $19 \%$ strongly disagreed with the assertion.

Thirdly, $90 \%$ of the respondents strongly affirmed that the adoption and applicability of I.R. would lead to increased funding from donors. This is especially so because investors would often require adequate information for investment decisions. This finding corroborates with that of Oshika and Saka (2017), who found that the economic motive for adopting I.R. was donor support.

Lastly, $45 \%$ of the respondents strongly agreed that I.R. applicability would expose corrupt deals; hence, it could restrain the powers' effective functioning. However, 25\% remained neutral while $30 \%$ strongly disagreed.

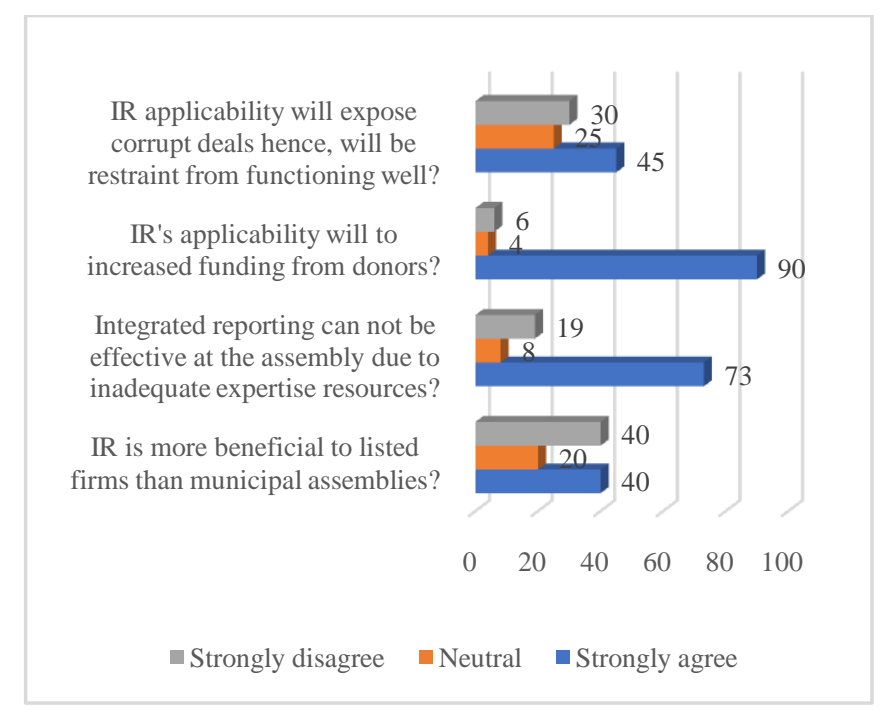

Figure 4.4. Effectiveness and applicability of I.R. at Asante Akim Central Source: Field Data (2021)

\subsection{Recommendations}

Against the backdrop of the above, the researcher recommends that:

4.3.1 The assembly endeavours to adopt I.R. within the

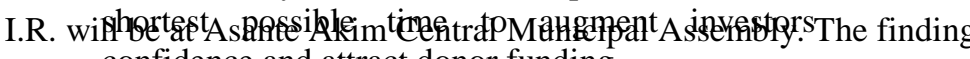
confidence and attract donor funding

4.3.2 The Assembly equips its staff with the requisite skills and provides logistics that could lead to swift adoption and implementation of I.R.

4.3.3 The study should be replicated in other assemblies to unravel the notion that integrated reporting is only valuable for listed firms.

\subsection{Conclusion}

The researcher concludes a high awareness of integrated reporting at the Assembly even though it has yet to adopt it fully. The study furthers that the adoption at the assembly 
level would boost public confidence and augment donor funds.

\section{REFERENCES}

[1] Abeysekera, I. (2013), "A template for integrated reporting", Journal of Intellectual Capital, Vol. 14 No. 2, pp. 227-245. https://doi.org/10.1108/14691931311323869

[2] Ackah, P., \& Lamptey, L.L. (2017). Corporate social responsibility reporting (CSRR) by the banking industry in a developing economy. Asian Journal of Economics, Business and Accounting, 2(3), 1-10

[3] Ackers, B., \& Eccles, N.S. (2015). Mandatory corporate social responsibility assurance practices: The case of King III in South Africa. Accounting, Auditing \& Accountability Journal, 28(4), 515-550.

[4] Adams, C. A. (2015). The international integrated reporting council: A call to action. Critical Perspectives on Accounting, 27, 23-28. https://doi. org/10.1016/j.cpa.2014.07.001

[5] Adhikariparajuli, Mahalaxmi, Abeer H., \& Fletcher M., (2021). Integrated Reporting Implementation and Core Activities Disclosure in U.K. Higher Education Institutions. Administrative Sciences 11: 86. https://doi.org/10.3390/admsci 11030086.

[6] Aras, G., Kutlu Furtuna, O. and Hacioglu Kazak, E. (2021), "Toward an integrated reporting framework in higher education institutions: evidence from a public university", International Journal of Sustainability in Higher Education, Vol. ahead-of-print No. ahead-of-print. https://doi.org/10.1108/IJSHE-12-2020-0504

[7] Awinbugri A.E., \& Boahen J., (2021) .IFRS Adoption and Earnings Quality in Sub-Saharan Africa. Int J Account Res. 9(3):204

[8] Bananuka, Juma, Zainabu T., \& Laura O., (2019). The adoption of integrated reporting: A developing country perspective. Journal of Financial Reporting and Accounting 17: 2-23.

[9] Beretta, V., C. Demartini, \& S. Trucco. (2019). State of the art of I.R. disclosure in Europe. A research agenda. Economia Aziendale Online 10 (2): 203-217.

[10] Camilleri, M.A. (2018). Theoretical insights on integrated reporting: The inclusion of non-financial capitals in corporate disclosures. Corporate Communications: An International Journal 23 (4): 567-581.
[11] Carol A. Adams (2018) Debate: Integrated reporting and accounting for sustainable development across generations by universities, Public Money \& Management, 38:5, 332-334, DOI: 10.1080/09540962.2018.1477580

[12] Deegan, C.M., (2019). Legitimacy theory. Accounting, Auditing \& Accountability Journal. 32 (8): 2307-2329.

[13] Ernst and Young. (2018). Ernst \& Young's Excellence in Integrated Reporting Awards, 2018. Retrieved from http://integratedreportingsa. org/ircsa/wpcontent/uploads/2018/08/ey-excellence-in-integrated- reportingawards-2018.pdf

[14] IIRC. (2013). The international < I.R.> framework. http://www.theiirc.org/wp-content/uploads.

[15] IIRC (2015). Applying the integrated reporting concept of 'capitals' in the banking industry.

[16] King Report IV. (2016). Corporate Governance for South Africa $2016 . \quad$ Available online: www.oidsa.co.za/resource/resmgr/king/_iv_ Report/IoDSA_King_IV_Report_-_WebVe.pdf .

[17] Maama H. \& Mkhize M., (2020). Integrated reporting practice in a developing country-Ghana: legitimacy or stakeholder oriented? International Journal of Disclosure and Governance.

[18] M.I.A., ACCA. (2016). MIA-ACCA integrated reporting survey contents. https://goo.gl/2tzi9o

[19] Omran, M. A., \& Ramdhony, D. (2015). Theoretical Perspectives on Corporate Social Responsibility Disclosure: A Critical Review. International Journal of Accounting and Financial Reporting, 5(2), 38. https://doi.org/10.5296/ijafr.v5i2.8035

[20] Oshika, T., \& Saka, C. (2017). Sustainability KPIs for integrated reporting. Social Responsibility Journal, 13(3), 625-642. https://doi.org/10.1108/SRJ-07-2016-0122

[21] Selimoglu, S.K. \& Yesilcelebi, G. (2021), "Integrated Reporting and Combined Assurance: A Qualitative Research on the Awareness in Turkey*", Özen, E., Grima, S. and Gonzi, R.D. (Ed.) New Challenges for Future Sustainability and Wellbeing (Emerald Studies in Finance, Insurance, and Risk Management), Emerald Publishing Limited, Bingley, pp. 463-482. https://doi.org/10.1108/978-1-80043-968-920211025

[22] Su, W., Peng, M. W., Tan, W., \& Cheung, Y.-L. (2016). The Signaling Effect of Corporate Social Responsibility in Emerging Economies. Journal of Business Ethics, 134(3), 479-491. https://doi.org/10.1007/s10551-014-2404-4 